\begin{tabular}{r|l|l|l}
$\begin{array}{r}\text { Case Reports in } \\
\text { Gastroenterology }\end{array}$ & $\begin{array}{l}\text { Case Rep Gastroenterol 2010;4:518-523 } \\
\text { DOl: 10.1159/000322871 }\end{array}$ & $\begin{array}{l}\text { Published online: } \\
\text { December 1, 2010 }\end{array}$ & $\begin{array}{l}\text { O 2010 S. Karger AG, Basel } \\
\text { ISSN 1662-0631 } \\
\text { www.karger.com/crg }\end{array}$ \\
\hline
\end{tabular}

This is an Open Access article licensed under the terms of the Creative Commons AttributionNonCommercial-NoDerivs 3.0 License (www.karger.com/OA-license), applicable to the online version of the article only. Distribution for non-commercial purposes only.

\title{
Recurrent Indigestion in a Young Adult
}

\author{
Erdinc Soylu ${ }^{a}$ Sameer Junnarkar ${ }^{b}$ Hemant M. Kocher ${ }^{a, b}$ \\ ${ }^{a}$ Barts and the London School of Medicine and Dentistry and bepartment of \\ Surgery, Barts and the London NHS Trust, The Royal London Hospital, London, UK
}

\author{
Key Words \\ Bochdalek hernia $\cdot$ Diaphragm · Gastrectomy $\cdot$ Hernia and dyspepsia
}

\begin{abstract}
Bochdalek hernias (BHs) arise due to congenital diaphragmatic defect and can result in gross displacement of abdominal tissues into the thorax. Although they are uncommon in occurrence, they usually present as serious respiratory distress in infants. In the adult population, they are asymptomatic and only detected incidentally. In this report, we present the case of a 26-year-old male who acutely presented with severe epigastric pain radiating to the back and deranged vital signs as a result of incorrect previous diagnoses. A large left diaphragmatic hernia containing his pancreatic tail, spleen, stomach and other intra-abdominal organs was confirmed by CT scan, together occupying a third of the hemithorax. Although not common, diagnostics of BHs should be considered in patients presenting with acute abdomen. A plain chest X-ray displaying diminished left diaphragmatic outline or signs of mediastinal shift should raise suspicion. Previous normal chest X-ray can be deceptive and does not rule out a diaphragmatic hernia. Herein, we also review the literature for previously reported acute presentation of 11 similar cases in adults and highlight the value of including $\mathrm{BH}$ as one of the differential diagnoses.
\end{abstract}

\section{Case Report}

A 26-year-old male presented with acute severe epigastric pain radiating to the back. After having seen various clinicians with a complaint of indigestion, both in the UK and in Poland, a definitive diagnosis had not been reached. The severe intermittent nature of indigestion had prompted his doctors to engage in a number of investigations, some of which included sonography and chest $\mathrm{X}$-ray (fig. 1a). He was working as a lifeguard in London and had previously been a security guard in Poland. He did not have a history of trauma, did not drink alcohol and had no significant past medical history.

Over the course of two months, he had presented to the accident and emergency service on three occasions with abdominal pain and vomiting, one of which culminated in an investigation for possible renal calculi. This third occasion was associated with severe retching and vomiting. He appeared in distress and was septic: blood pressure 190/120 $\mathrm{mm} \mathrm{Hg}$, heart rate 160 beats/min and temperature

Hemant M. Kocher, MS, MD, FRCS Centre for Tumour Biology, Institute of Cancer Barts and the London School of Medicine and Dentistry

Charterhouse Square, London EC1M 6BQ (UK)

Tel. +44 207882 3579, Fax +44 2078823884

E-Mail hemant.kocher@bartsandthelondon.nhs.uk 


\begin{tabular}{r|l|l|l} 
Case Reports in & $\begin{array}{l}\text { Case Rep Gastroenterol 2010;4:518-523 } \\
\text { DOl: 10.1159/000322871 }\end{array}$ & $\begin{array}{l}\text { Published online: } \\
\text { December 1, 2010 }\end{array}$ & $\begin{array}{l}\odot \text { ISSN 1662-0631 } \\
\text { www.karger.com/crg }\end{array}$ \\
\hline
\end{tabular}

$39.2^{\circ} \mathrm{C}$. His epigastrium was tender and there were decreased breath sounds in the left lower zone. His blood tests revealed raised CRP (262 mg/l) and serum amylase (500 IU/l).

Herniation through the diaphragm and right mediastinal shift was clearly visible from chest X-ray (fig. 1b). Further CT imaging revealed a large posterolateral diaphragmatic hernia (Bochdalek's foramen) containing his pancreatic tail, spleen, distended stomach, small bowel and transverse colon (occupying a third of the left hemithorax) (fig. 1c). Endoscopy failed to negotiate pylorus and resulted in transient relief of symptoms. Continuing severe pain and respiratory compromise led to laparotomy: bleeding short gastric vessels, a necrotic first past of the duodenum and the fundus of the stomach was discovered. Duodenectomy (first part), partial gastrectomy (fundus), splenectomy, gastrojejunostomy and repair of the hernial defect (Proceed ${ }^{\mathrm{TM}}$ mesh) were performed. He remains asymptomatic after two years of follow-up.

\section{Discussion}

Bochdalek hernia $(\mathrm{BH})$ is a congenital condition that is characterised by failure of the posterolateral part of the diaphragm to develop and form a complete barrier. It accounts for about $90 \%$ of diaphragmatic hernias [1], with a prevalence rate of around 1 in 3,000 live births [2]. It presents in the neonatal period and was first described in 1848 by Vincent Alexander Bochdalek [3]. This type of diaphragmatic hernia most commonly occurs on the left side of the chest as the closure of the pleuroperitoneal canal is completed later on this side [4].

The clinical features of congenital diaphragmatic hernias include severe respiratory distress, cyanosis, scaphoid abdomen, decreased or diminished breath sounds (on the same side of the defect), displaced heart sounds (away from the defect) and presence of bowel sounds in the chest. An upright thoracic X-ray image may show signs of bowel gas in the thorax, diminished diaphragmatic outline and mediastinal shift [5]. Half of the patients with congenital diaphragmatic hernias are detected during the prenatal period either by ultrasound or MRI investigation.

Over one hundred instances of $\mathrm{BH}$ have been reported in adults in the medical literature [6]. Undiscovered cases are usually asymptomatic in adults and only detected incidentally [7] with a prevalence rate ranging between 0.17 and $12.7 \%$ [8, 9]. Perhaps the widespread use of multi-detector row computed tomography has contributed to an increased rate of diagnoses [7]. In a screening study conducted on a large cohort of healthy adult population (mean age 62.8 years), the prevalence of posterior transdiaphragmatic hernia was found to be $12.7 \%$ (396 individuals out of 3,107). All of the subjects were asymptomatic [8]. In another retrospective study based on abdominal CT reports of 13,138 hospital inpatients, the reported prevalence rate was $0.17 \%$ (mean age 66.6 years) for incidental $\mathrm{BH}$ [9]. The analysis of similar case reports or larger studies does not indicate a particular pattern of relationship between incidental hernia and BMI, gender or age of patients [7].

Misdiagnosis is common for $\mathrm{BH}$, reported to be $38 \%$ by Thomas and Kapur [10]. It is very crucial that it is diagnosed early in order to avoid unnecessary interventions and complications such as strangulation of the abdominal viscera. Up to date, 173 patients with this condition have been reported in the literature. A recent review by Brown et al. demonstrates that trends such as an inciting event, which underlie an increase in intra-abdominal pressure, may be found in as many as $25 \%$ of patients prior to acute presentation [11]. Gastrointestinal disturbance and presence of bowel sounds in 


\begin{tabular}{r|l|l|l}
$\begin{array}{r}\text { Case Reports in } \\
\text { Gastruenterology }\end{array}$ & $\begin{array}{l}\text { Case Rep Gastroenterol 2010;4:518-523 } \\
\text { DOI: 10.1159/000322871 }\end{array}$ & $\begin{array}{l}\text { Published online: } \\
\text { December 1, 2010 }\end{array}$ & $\begin{array}{l}\text { O 2010 S. Karger AG, Basel } \\
\text { ISSN 1662-0631 } \\
\text { www.karger.com/crg }\end{array}$ \\
\hline
\end{tabular}

association with diminished breath sounds in a single hemithorax are some of the suggestive clinical signs [12]. Chest or abdominal pain seem to be the most frequently presenting complaints reported in $69 \%$ of patients [11]. A literature review of 173 cases reported by Brown et al. showed that in $78 \%$ of patients the hernia was located on the left side of the chest [11].

During our literature search, we came across 11 patients who also presented acutely and had symptoms for less than a month (table 1). In a majority of patients, gastrointestinal symptoms predominated. Yet again, this case report signifies the importance of diagnostic consideration of $\mathrm{BH}$ in an adult patient presenting with acute gastrointestinal symptoms, despite the presence of unusual septic features.

Various imaging modalities have been used. Computed tomography is able to provide information on the anatomical position of the organs and remains the best preoperative investigation in an emergency setting. A plain X-ray displaying diminished left diaphragmatic outline, signs of mass pressure or mediastinal shift should raise suspicion [12]. A previous normal chest X-ray does not rule out a diaphragmatic hernia, as the defect may be sealed up by the spleen or by the presence of a confining sac [10].

\section{Conclusion}

Diaphragmatic hernias should be considered in patients presenting with an acute abdomen and at the very least a thorough auscultation over the chest and a chest X-ray should be carried out. A previous normal chest X-ray does not rule out a diaphragmatic hernia, as the defect may be sealed up by the spleen or by the presence of a confining sac. Gastrointestinal symptoms in combination with sepsis should not exclude the possibility of BH. Gastrointestinal disturbances with left lung signs should prompt suspicion of this condition.

\section{Disclosure Statement}

The authors have no conflicts of interest to declare. 
Table 1. Previous reports of $\mathrm{BH}$ presenting in an acute setting

\begin{tabular}{|c|c|c|c|c|c|c|}
\hline $\begin{array}{l}\text { Kavanagh } \\
{[13]}\end{array}$ & $1 / 76 / \mathrm{M}$ & $\begin{array}{l}\text { dyspnoea, abdominal } \\
\text { distension, constipation }\end{array}$ & $\begin{array}{l}\text { strangulated } \\
\text { transverse colon }\end{array}$ & CXR, CT & $\begin{array}{l}\text { laparotomy to } \\
\text { resect necrosed } \\
\text { segment of the } \\
\text { colon }\end{array}$ & none \\
\hline $\begin{array}{l}\text { Lucisano } \\
{[14]}\end{array}$ & $1 / 45 / \mathrm{F}$ & $\begin{array}{l}\text { 4-day history of epigastric } \\
\text { pain }\end{array}$ & $\begin{array}{l}\text { incomplete intestinal } \\
\text { malrotation and } \\
\text { volvulus of right } \\
\text { colon }\end{array}$ & $\begin{array}{l}\text { CXR, CT, } \\
\text { barium enema }\end{array}$ & $\begin{array}{l}\text { right } \\
\text { hemicolectomy }\end{array}$ & none \\
\hline $\begin{array}{l}\text { Palanivelu } \\
{[16]}\end{array}$ & $1 / 23 / \mathrm{F}$ & $\begin{array}{l}\text { 1-month duration of } \\
\text { vomiting, epigastric pain, } \\
\text { oliguria and dyspnoea }\end{array}$ & gastric volvulus & $\begin{array}{l}\text { CXR, CT, } \\
\text { abdominal } \\
\text { ultrasound }\end{array}$ & laparoscopy & none \\
\hline $\begin{array}{l}\text { Dalton } \\
{[17]}\end{array}$ & $1 / 43 / \mathrm{M}$ & $\begin{array}{l}\text { abdominal pain and } \\
\text { dyspnoea }\end{array}$ & gas-filled stomach & CXR & laparotomy & none \\
\hline $\begin{array}{l}\text { Losanoff } \\
{[18]}\end{array}$ & $1 / 29 / \mathrm{M}$ & $\begin{array}{l}\text { periumbilical pain } \\
\text { associated with nausea } \\
\text { and vomiting }\end{array}$ & & $\mathrm{CT}$ & $\begin{array}{l}\text { emergency } \\
\text { laparotomy }\end{array}$ & $\begin{array}{l}\text { after } 2 \text { months } \\
\text { the patient is } \\
\text { well and } \\
\text { asymptomatic }\end{array}$ \\
\hline $\begin{array}{l}\text { Habib } \\
{[21]}\end{array}$ & $\begin{array}{l}3 / \\
27,38,88 / \\
\text { unknown }\end{array}$ & $\begin{array}{l}\text { small bowel obstruction; } \\
\text { epigastric pain and gastric } \\
\text { obstruction; respiratory } \\
\text { failure and gastric } \\
\text { obstruction }\end{array}$ & & $\begin{array}{l}\text { CXR, CT, } \\
\text { barium meal; } \\
\text { CT, barium } \\
\text { enema; CXR, } \\
\text { CT }\end{array}$ & $\begin{array}{l}\text { laparotomy } \\
(\mathrm{n}=2) ; \\
\text { thoracotomy } \\
(\mathrm{n}=1)\end{array}$ & $\begin{array}{l}\text { one } \\
\text { postoperative } \\
\text { death }\end{array}$ \\
\hline $\begin{array}{l}\text { Seidenverg } \\
{[22]}\end{array}$ & $1 / 20 / \mathrm{F}$ & $\begin{array}{l}\text { left chest pain, nausea and } \\
\text { vomiting }\end{array}$ & & $\begin{array}{l}\text { CXR, roent- } \\
\text { genographic } \\
\text { visualisation of } \\
\text { nasogastric tube }\end{array}$ & laparotomy & $\begin{array}{l}\text { well at } 12 \\
\text { months }\end{array}$ \\
\hline
\end{tabular}




\begin{tabular}{r|l|l|l} 
Case Reports in & $\begin{array}{l}\text { Case Rep Gastroenterol 2010;4:518-523 } \\
\text { DOI: } 10.1159 / 000322871\end{array}$ & $\begin{array}{l}\text { Published online: } \\
\text { December 1, 2010 }\end{array}$ & $\begin{array}{l}\text { ISSN 1662-0631 } \\
\text { wwww.karger.com/crg }\end{array}$ \\
\hline
\end{tabular}
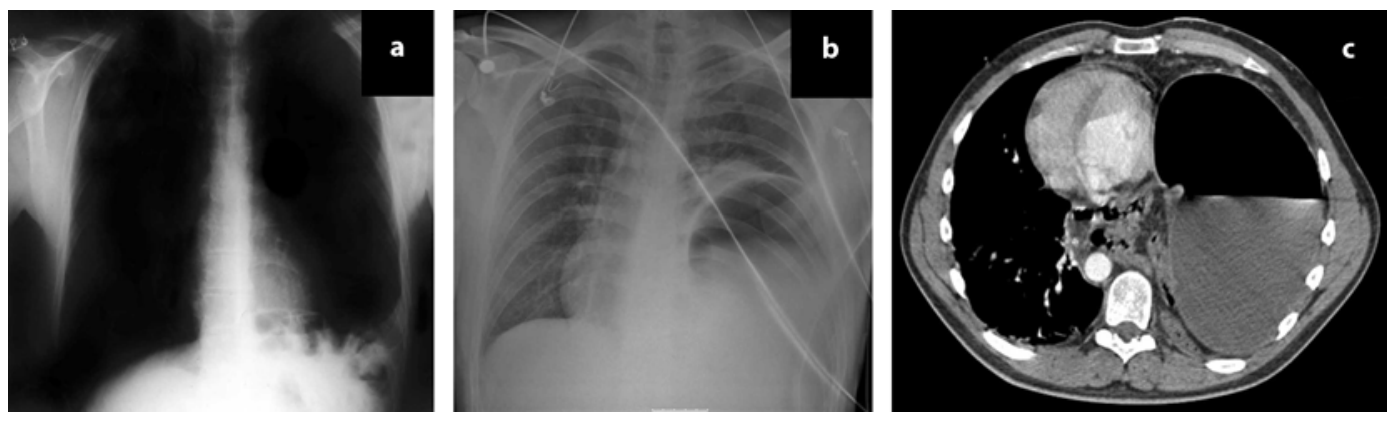

Fig. 1. a Old plain chest X-ray (two years before presentation), which was essentially normal. b Chest $\mathrm{X}$-ray at presentation. Mediastinal shift towards the right hemithorax, a vague left cardiophrenic angle and a raised left hemidiaphragm clearly demonstrate herniation through the left hemidiaphragm. c CT scan of the upper abdomen. Large posterolateral diaphragmatic hernia containing distended stomach, occupying the whole left hemithorax.

\section{References}

1 Morris JM, Malt RA: Oxford Textbook of Surgery, vol 2. New York, Oxford University Inc., 1994.

-2 Langham MR Jr, Kays DW, Ledbetter DJ, Frentzen B, Sanford LL, Richards DS: Congenital diaphragmatic hernia: epidemiology and outcome. Clin Perinatol 1996;23:671-688.

3 Bochdalek VA: Einige Betrachtungen über die Entstehung des angeborenen Zwerchfellbruches als Beitrag zur pathologischen Anatomie der Hernien. Vrtljschr Prakt Heilkd 1848;19:89.

4 Bujanda L, Larrucea I, Ramos F, Munoz C, Sanchez A, Fernandez I: Bochdalek's hernia in adults. J Clin Gastroenterol 2001;32:155-157.

5 Pober BR, Russell MK, Ackerman KG: Congenital diaphragmatic hernia overview; in Pagon RA, Bird TC, Dolan CR, Stephens K (eds): GeneReviews (Internet). Seattle (WA), University of Washington, ๑1993-2009 (updated March 16, 2010). http://www.ncbi.nlm.nih.gov/bookshelf/br.fcgi?book=gene\&log $\$=$ disease_name \&part=cdh-ov.

6 Cosenza UM, Raschellà GF, Giacomelli L, Scicchitano F, Simone M, Cancrini G, Zofrea P, Cancrini A: The Bochdalek hernia in the adult: case report and review of the literature. G Chir 2004;25:175-179.

-7 Temizoz O, Genchellac H, Yekeler E, Umit H, Unlu E, Ozdemir H, Demir MK: Prevalence and MDCT characteristics of asymptomatic Bochdalek hernia in adult population. Diagn Interv Radiol 2010;16:52-55.

8 Kinoshita F, Ishiyama M, Honda S, Matsuzako M, Oikado K, Kinoshita T, Saida Y: Late-presenting posterior transdiaphragmatic (Bochdalek) hernia in adults: prevalence and MDCT characteristics. J Thorac Imaging 2009;24:17-22.

9 Mullins ME, Stein J, Saini SS, Mueller PR: Prevalence of incidental Bochdalek's hernia in a large adult population. AJR Am J Roentgenol 2001;177:363-366.

10 Thomas S, Kapur B: Adult Bochdalek hernia - clinical features, management and results of treatment. Jpn J Surg 1991;21:114-119.

11 Brown SR, Horton JD, Trivette E, Hofmann LJ, Johnson JM: Bochdalek hernia in the adult: demographics, presentation, and surgical management. Hernia 2010, Epub ahead of print.

$\checkmark 12$ Eren S, Ciriş F: Diaphragmatic hernia: diagnostic approaches with review of the literature. Eur J Radiol 2005;54:448-459.

13 Kavanagh DO, Ryan RS, Waldron R: Acute dyspnoea due to an incarcerated right-sided Bochdalek's hernia. Acta Chir Belg 2008;108:604-606.

14 Lucisano AM, Pafundi DP, Calabria R, Orsini V, Sacco R: Congenital diaphragmatic hernia in an adult: case report of acute abdomen. Chir Ital 2008;60:583-586.

-15 Harrington DK, Curran FT, Morgan I, Yiu P: Congenital Bochdalek hernia presenting with acute pancreatitis in an adult. J Thorac Cardiovasc Surg 2008;135:1396-1397.

16 Palanivelu C, Rangarajan M, Maheshkumaar GS, Parthasarathi R: Laparoscopic mesh repair of a Bochdalek diaphragmatic hernia with acute gastric volvulus in a pregnant patient. Singapore Med J 2008;49:26-28. 
17 Dalton AM, Hodgson RS, Crossley C: Bochdalek hernia masquerading as a tension pneumothorax. Emerg Med J 2004;21:393-394.

18 Losanoff JE, Sauter ER: Congenital posterolateral diaphragmatic hernia in an adult. Hernia 2004;8:83-85.

19 Kanazawa A, Yoshioka Y, Inoi O, Murase J, Kinoshita H: Acute respiratory failure caused by an incarcerated right-sided adult Bochdalek hernia: report of a case. Surg Today 2002;32:812-815.

20 Harinath G, Senapati PS, Pollitt MJ, Ammori BJ: Laparoscopic reduction of an acute gastric volvulus and repair of a hernia of Bochdalek. Surg Laparosc Endosc Percutan Tech 2002;12:180-183.

-21 Habib E, Bellaïche G, Elhadad A: Complications of misdiagnosed Bochdalek hernia in adults. Literature review. Ann Chir 2002;127:208-214.

22 Seidenverg NF: Foramen of Bochdalek hernia with acute tension of displaced organs. Calif Med 1971;114: $39-41$ 